\title{
Genetic Differences in Natural and Cultured River Pufferfish Populations by PCR Analysis
}

\author{
${ }^{\dagger} J$ ong-Man Yoon \\ Department of Aquatic Life Medicine, College of Ocean Science and Technology, Kunsan National University, Gunsan \\ 54150, Korea
}

Received: November 5, 2020

Revised: November 13, 2020

Accepted: November 22, 2020

${ }^{\dagger}$ Corresponding author Jong-Man Yoon

Department of Aquatic Life Medicine, College of Ocean Science and Technology, Kunsan National University, Gunsan 54150, Korea.

Tel: +82-63-469-1887

E-mail:jmyoon@kunsan.ac.kr

Copyright $\odot 2020$ The Korean Society of Developmental Biology.

This is an Open Access article distributed under the terms of the Creative Commons Attribution Non-Commercial License (http://creativecommons.org/licenses/ by-nc/4.0/) which permits unrestricted non-commercial use, distribution, and reproduction in any medium, provided the original work is properly cited.

ORCID

Jong-Man Yoon

https://orcid.org/0000-0003-2825-681X

Conflict of interests

The authors declare no potential conflict of interest.

\section{Acknowledgements}

Not applicable.

\section{Authors' contributions}

The article is prepared by a single author.

\section{Ethics approval}

This article does not require IRB/IACUC approval because there are no human and animal participants.

\section{Abstract}

Genomic DNA (gDNA) extracted from two populations of natural and cultured river pufferfish (Takifugu obscurus) was amplified by polymerase chain reaction (PCR). The complexity of the fragments derived from the two locations varied dramatically. The genetic distances (GDs) between individuals numbered 15 and 12 in the cultured population was 0.053 , which was the lowest acknowledged. The oligonucleotide primer OPC-11 identified 88 unique loci shared within each population reflecting the natural population. The OPC-05 primer identified 44 loci shared by the two populations. The average band-sharing (BS) values of individuals in the natural population $(0.683 \pm 0.014)$ were lower than in those derived from the cultured population $(0.759 \pm 0.009)(p<0.05)$. The shortest GD demonstrating a significant molecular difference was found between the cultured individuals \# 15 and \# 12 (GD=0.053). Individual \# 02 of the natural population was most distantly related to cultured individual \# 22 (GD=0.827). A cluster tree was built using the unweighted pair group method with arithmetic mean (UPGMA) Euclidean GD analysis based on a total of 578 various fragments derived from five primers in the two populations. Obvious markers identified in this study represent the genetic structure, species security, and proliferation of river pufferfish in the rivers of the Korean peninsula.

Keywords: Hierarchical polar dendrogram, River pufferfish, Similarity matrix, Takifugu obscurus, Unweighted pair group method with arithmetic (UPGMA) Euclidean genetic distance

\section{INTRODUCTION}

Takifugu obscurus is a migratory fish belonging to the family Tetraodontidae and order Tetraodontiformes, widely distributed on the coast of the Yellow Sea, the southern sea in the Korean peninsula, and some parts of the South China Sea. In the natural environment, the benthic river pufferfish inhabit the bottom zones, laying eggs under pebbles. They carry yellow stripes laterally with a dark-brown dorsal body and white abdomen. These pufferfish are rounded- and club-bodied with black spots detected on the pectoral and dorsal fins. Adult river pufferfish eat small crustaceans, small fish, fish eggs, and other food. They represent some of the finfish species, which are socioeconomically significant in many seashore regions. 
However, despite their significant importance to fish conservation and systematic analysis, the reproductive, biochemical, and environmental aspects of river pufferfish species in Korea are unknown. Nevertheless, the pufferfish are distinct sitologically (Kang et al., 2007), nutritionally (Yoo \& Bai, 2014; Yoo et al., 2014), ultrastructurally (Kim et al., 2003), reproductively (Chang et al., 1999; Kang et al., 2008), as well as environmentally (Lee et al., 2004a; Lee et al., 2004b). However, few genetic or molecular studies have comparatively analyzed finfish with other invertebrates. It is essential to elucidate the genetic traits and composition of the pufferfish population in order to appreciate its genetic value.

Comprehensive genetic markers specific to breeds, species, genera, and/or geographical populations have been used to identify and distinguish individuals, populations, and hybrid pedigrees based on molecular genetic analysis (Callejas \& Ochando, 1998; Mamuris et al., 1999; Adams, 2000; Bartish et al., 2000; Kim et al., 2000; Klinbunga et al., 2000b; McCormack et al., 2000; Nebauer et al., 2000; Nozaki et al., 2000; Chenyambuga et al., 2004; Kim et al., 2006; Yoon \& Kim, 2010; Hur et al., 2012; Kim \& Yoon, 2018). Polymerase chain reaction (PCR) techniques have been used in mariculture and aquaculture to determine the genetic distances (GDs) between teleost species and/or invertebrates as well as geographic distribution (Tassanakajon et al., 1998; Huang et al., 2000; Klinbunga et al., 2000a; Zhou et al., 2000; Yoon \& Park, 2002; Kim et al., 2004; Park et al., 2005; Song \& Yoon, 2013; Oh \& Yoon, 2014; Yoon, 2019).

River pufferfish farming is an aquaculture dream. In an effort to upgrade river pufferfish aquaculture, this study elucidates the GDs and variations between natural and cultured river pufferfish populations. A cluster analysis of two river pufferfish populations (natural and cultured) was also performed.

\section{MATERIALS AND METHODS}

Individual tissue samples were collected from natural and cultured river pufferfish populations. Dorsal muscle samples were obtained from the trunk of 22 individuals anesthetized with MS 222 (100 ppm) and transferred into disinfected vials. The muscles were extracted into sterile tubes carried on ice, and stored at $-40^{\circ} \mathrm{C}$ until used. DNA extraction was performed according to the separation and removal methods described previously (Oh \& Yoon, 2014). Chloroform (500 $\mu \mathrm{L})$ was added to the mixture and then inverted (without phenol). After a few washes, the dorsal muscle tissue samples were transferred into $10 \mathrm{~mL}$ test tubes filled with $30 \mathrm{~mL}$ of lysis buffer. The tubes were lightly inverted. The tissue precipitates were detached with lysis buffer. Proteinase $\mathrm{K}$ solution $(20 \mu \mathrm{L}, 15 \mathrm{mg} / \mathrm{mL})$ was added to the dorsal samples and incubated, followed by careful addition of $300 \mu \mathrm{L}$ of $6 \mathrm{M} \mathrm{NaCl}$. The DNA pellets were dried under incubation for $3 \mathrm{~h}$, stored at $-90^{\circ} \mathrm{C}$ until analysis, and thawed in TE buffer. The optical density of the refined genomic DNA (gDNA) was quantified spectrophotometrically by the absorbance at $260 \mathrm{~nm}$. The DNA globules were then dried under incubation at $2{ }^{\circ} \mathrm{C}$ for more than $10 \mathrm{~h}$, stored at $-90^{\circ} \mathrm{C}$ until needed, and thawed in purified distilled water.

The oligonucleotides primers were purchased from Operon Technologies, USA. OPC-03 (5'-GGGGGTCTTT-3'), OPC-05 (5'-GATGACCGCC-3'), OPC06 (5'-GAACGGACTC-3'), OPC-07 (5'-GTCCCGACGA-3'), and OPC-11 (5'-AAAGCTGCGG-3') were the primers used to identify the unique loci shared within each population and the number of loci shared by the two river pufferfish populations was calculated. The oligonucleotide primers were also used to identify genetic variations, DNA polymorphisms, and pairwise similarity of the river pufferfish in the natural and the cultured fish populations. 
PCR analysis was performed on a programmable DNA Thermal Cycler (MJ Research, Waltham, MA, USA). DNA amplification was performed with $25 \mu \mathrm{L}$ sample aliquots containing $10 \mathrm{ng}$ of template DNA, $22 \mu \mathrm{L}$ of premix (Bioneer, Daejeon, Korea), and 1 unit of primer. Electrophoresis of the amplification reaction was conducted for $30 \mathrm{~min}$ at $100 \mathrm{~V}$ in a $1.4 \%$ agarose (Bioneer) gel containing ethidium bromide in TBE buffer ( $90 \mathrm{mM}$ Tris, $\mathrm{pH} 8.5 ; 90 \mathrm{mM}$ borate; and 2.5 mM EDTA) using a 100 bp DNA ladder (Bioneer) as a DNA molecular weight marker. The electrophoresed agarose gels were irradiated with UV rays, and images were acquired using a Photoman Direct Copy System (PECA Products, Beloit, WI, USA).

Similarity matrices containing band-sharing $(\mathrm{BS})$ values were designed along with or without the amplified products at specific spots in the identical gel from the DNA frameworks. The BS values estimated were consistent with those reported by Jeffreys \& Morton (1987) and YokeKqueen \& Radu (2006). Comparing the two lanes, the BS value was calculated as follows: $B S=2(\mathrm{Nab}) /(\mathrm{Na}+\mathrm{Nb})$, where $\mathrm{Nab}$ denotes the number of fragments shared by samples $\mathrm{b}$ and $\mathrm{a}$; $\mathrm{Na}$ indicates the total number of fragments in $\mathrm{a}$; and $\mathrm{Nb}$ represents the total number of fragments in sample b. The average within-population similarity was measured via pairwise parallel analysis between the individuals within a population. The relationship between different individuals in the river pufferfish populations was determined using the BS values and similarity matrices. A hierarchical polar dendrogram was constructed based on similarity matrices to yield a cluster tree using Systat version 10 (SPSS, Chicago, IL, USA). The Systat software was also used to analyze the Euclidean GDs within and between the river pufferfish populations, means, standard errors, and $t$-test results.

\section{RESULTS AND DISCUSSION}

Five oligonucleotide primers OPC-03, OPC-05, OPC-06, OPC-07, and OPC-11 were used to generate the unique loci shared within each population and the loci shared by the two river pufferfish populations. The complexity of the banding profiles varied greatly between the primers derived from the two pufferfish populations. The fragment numbers in each size range were based on the integrated fragments amplified by the five oligonucleotides primers, as shown in Fig. 1.

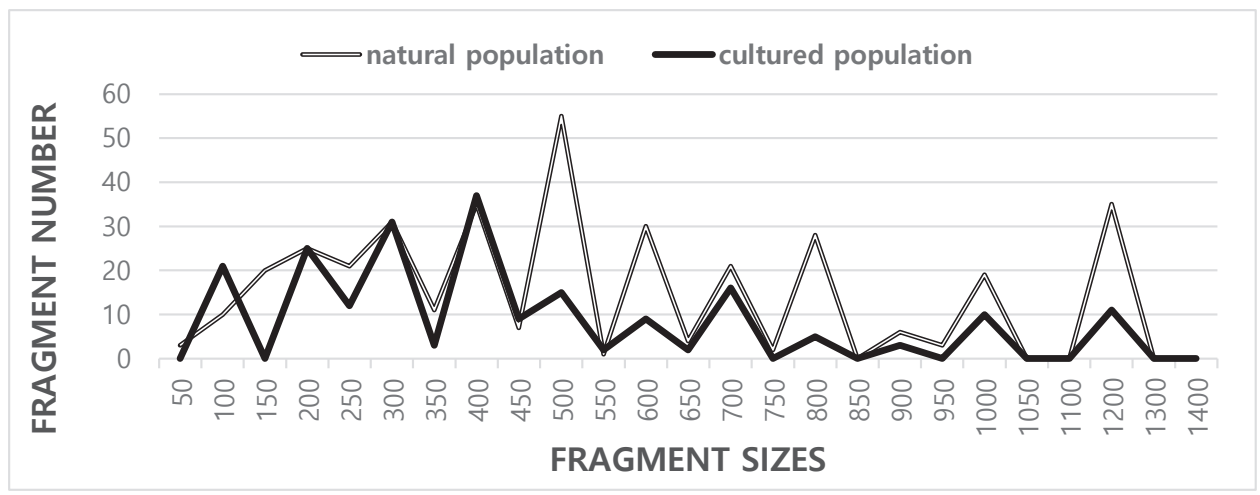

Fig. 1. Sprinkling of fragment sizes of two natural and cultured river pufferfish population, respectively. Solid grey lines: natural population. Solid black lines: cultured population. The fragment numbers in each size graphics have been calculated from the pooled fragments become with every five oligonucleotides primers. Five oligonucleotides primers generated a total 367 fragments in the natural population and 211 fragments in the cultured population with the DNA fragment size ranging from $50 \mathrm{bp}$ to $1,300 \mathrm{bp}$. The higher fragment sizes (>1,400 bp) are not detected in the two river puffer populations. 
The size of the DNA fragments also varied widely, from $50 \mathrm{bp}$ to 1,300 bp, as indicated in Fig. 1 . Higher fragment sizes ( $>1,400 \mathrm{bp})$ are not recognized in the two river pufferfish populations. In this finfish, a cluster tree was constructed using the unweighted pair group method with arithmetic mean (UPGMA) Euclidean GD analysis of a total of 578 discrete fragments acquired with the five oligonucleotide primers from the two river pufferfish populations. The five oligonucleotide primers yielded a total of 367 fragments in the natural population and 211 fragments in the cultured population, with DNA fragment sizes ranging from $50 \mathrm{bp}$ to $1,300 \mathrm{bp}$. The average number of distinct fragments per primer within the natural and cultured river pufferfish population was 14.68 and 8.44 , respectively.

The number of fragments generated by each primer in the three endemic Spanish barbel species (Barbus bocagei, B. graellsii, and B. sclateri) varied from 17 to 30, with a mean of 24.2 bands per individual and primer (Callejas \& Ochando, 1998). The number of recorded fragments fluctuated from 7 to 12 per primer in four species belonging to familye Mullidae (Mamuris et al., 1999). In teleosts, DNA fragments ranging from $350 \mathrm{bp}$ to $700 \mathrm{bp}$ were detected via random amplified polymorphic DNA (RAPD-PCR) analysis of barramundi (Lates calcarifer) (Partis \& Wells, 1996). Tandem repeat sequences containing 290 bp to 291 bp of DNA were identified by Sall digestion of the gDNA from five species of Eastern Pacific abalone using another molecular method (genus Haliotis) (Muchmore et al., 1998). Eighty fragments ranging from $200 \mathrm{bp}$ to 2,200 bp were unambiguously counted in the black tiger shrimp (Penaeus monodon) (Tassanakajon et al., 1998). The fragment size ranged from $220 \mathrm{bp}$ to 1,700 bp in four species of the Mullidae family (Mamuris et al., 1999). The DNA fragments generated by four primers varied from $100 \mathrm{bp}$ to 2,300 bp in the brittle star (Amphiura filiformis) (McCormack et al., 2000). A phylogenetic tree was constructed via UPGMA cluster analysis based on a total of 3,744 distinguishable fragments in gynogenetic clones from the silver crucian carp, Carassius auratus gibelio (Block) (Zhou et al., 2000). The primer OPF10 yielded 11 amplified fragments in the eastern Pacific yellowfin tuna (Thunnus albacares), with sizes ranging from $200 \mathrm{bp}$ to $600 \mathrm{bp}$ (Diaz-Jaimes \& Uribe-Alcocer, 2003).

The BS value between individual \# 01 of the natural river pufferfish and \# 22 of the cultured river pufferfish was 0.173 , which was the lowest observed, as shown in Table 1 . The BS value between individuals \# 09 and \# 10 was 0.894 , which was the highest value within the natural river pufferfish population. The 88 unique loci shared between the populations generated by OPC-11 oligonucleotide primers were detected in the natural river pufferfish population, as shown in Table 2. The oligonucleotide OPC- 05 primers generated 55 unique loci shared within each population, which were identified within each natural river pufferfish population (Table 2). The oligonucleotide OPC-07 primer generated 44 unique shared loci within each population of the cultured river pufferfish. The oligonucleotide OPC- 05 primer revealed 44 loci shared by all the samples of the two river pufferfish populations, as major and/or minor fragments of $500 \mathrm{bp}$ and 1,200 bp, respectively (Table 2). The remaining oligonucleotide primers did not reveal any loci shared by the two populations. The average number of unique loci shared within each population was diverse and 1.6-fold higher in the natural than in the cultured population. Thirty-three loci were shared by three hard clam (Meretrix lusoria) populations with an average of 4.7 per primer (Yoon et al., 2012). The decamer primer BION-B14 generated 7 unique loci of approximately 100 bp in Vietnamese cuttlefish (Sepia esculenta) populations (Yoon \& Kim, 2010). Remarkably, the 21 unique shared loci within each population identified by BION-06 primer in a Sockcho cuttle fish population were approximately $100 \mathrm{bp}, 450 \mathrm{bp}$ and $650 \mathrm{bp}$ in size.

Individuals in the natural river pufferfish population $(0.683 \pm 0.014)$ had lower BS values than did individuals from the cultured river pufferfish population $(0.759 \pm 0.009)(\mathrm{p}<0.05)$, as shown in Table 3. The average $\mathrm{BS}$ value in this study was higher than the value between a common carp species and 
Table 1. Pairwise comparisons of similarity comprising individual bandsharing values investigated from Takifugu obscurus

\begin{tabular}{|c|c|c|c|c|c|c|c|c|c|c|c|c|c|c|c|c|c|c|c|c|c|c|}
\hline \multicolumn{23}{|c|}{ Bandsharing values } \\
\hline \multicolumn{12}{|c|}{ From natural river pufferfish } & \multicolumn{11}{|c|}{ From cultured river pufferfish } \\
\hline & 1 & 2 & 3 & 4 & 5 & 6 & 7 & 8 & 9 & 10 & 11 & 12 & 13 & 14 & 15 & 16 & 17 & 18 & 19 & 20 & 21 & 22 \\
\hline 1 & - & 0.800 & 0.766 & 0.703 & 0.630 & 0.562 & 0.605 & 0.576 & 0.566 & 0.508 & 0.538 & 0.287 & 0.276 & 0.344 & 0.282 & 0.324 & 0.256 & 0.333 & 0.269 & 0.184 & 0.309 & 0.173 \\
\hline 2 & & - & 0.810 & 0.755 & 0.644 & 0.606 & 0.677 & 0.636 & 0.550 & 0.507 & 0.635 & 0.260 & 0.275 & 0.327 & 0.260 & 0.292 & 0.292 & 0.289 & 0.256 & 0.255 & 0.255 & 0.247 \\
\hline 3 & & & - & 0.828 & 0.775 & 0.699 & 0.633 & 0.687 & 0.615 & 0.561 & 0.609 & 0.341 & 0.296 & 0.442 & 0.388 & 0.306 & 0.345 & 0.342 & 0.320 & 0.280 & 0.348 & 0.264 \\
\hline 4 & & & & - & 0.759 & 0.663 & 0.667 & 0.630 & 0.551 & 0.494 & 0.601 & 0.370 & 0.383 & 0.371 & 0.392 & 0.367 & 0.348 & 0.385 & 0.362 & 0.313 & 0.341 & 0.208 \\
\hline 5 & & & & & - & 0.799 & 0.661 & 0.675 & 0.667 & 0.622 & 0.676 & 0.348 & 0.343 & 0.333 & 0.356 & 0.233 & 0.233 & 0.264 & 0.248 & 0.191 & 0.283 & 0.200 \\
\hline 6 & & & & & & - & 0.761 & 0.792 & 0.850 & 0.756 & 0.830 & 0.354 & 0.391 & 0.294 & 0.371 & 0.308 & 0.350 & 0.346 & 0.317 & 0.330 & 0.362 & 0.378 \\
\hline 7 & & & & & & & - & 0.651 & 0.641 & 0.651 & 0.732 & 0.343 & 0.415 & 0.328 & 0.397 & 0.359 & 0.422 & 0.423 & 0.377 & 0.382 & 0.380 & 0.377 \\
\hline 8 & & & & & & & & - & 0.875 & 0.815 & 0.793 & 0.327 & 0.329 & 0.302 & 0.369 & 0.352 & 0.328 & 0.364 & 0.294 & 0.294 & 0.376 & 0.315 \\
\hline 9 & & & & & & & & & - & 0.894 & 0.830 & 0.395 & 0.357 & 0.310 & 0.403 & 0.344 & 0.293 & 0.380 & 0.360 & 0.374 & 0.413 & 0.350 \\
\hline 10 & & & & & & & & & & - & 0.775 & 0.442 & 0.380 & 0.318 & 0.429 & 0.360 & 0.337 & 0.413 & 0.392 & 0.409 & 0.433 & 0.384 \\
\hline 11 & & & & & & & & & & & - & 0.474 & 0.420 & 0.353 & 0.487 & 0.489 & 0.486 & 0.528 & 0.547 & 0.569 & 0.377 & 0.402 \\
\hline 12 & & & & & & & & & & & & - & 0.736 & 0.725 & 0.839 & 0.710 & 0.661 & 0.803 & 0.768 & 0.785 & 0.737 & 0.667 \\
\hline 13 & & & & & & & & & & & & & - & 0.778 & 0.771 & 0.803 & 0.817 & 0.710 & 0.825 & 0.708 & 0.827 & 0.690 \\
\hline 14 & & & & & & & & & & & & & & - & 0.758 & 0.878 & 0.680 & 0.718 & 0.781 & 0.739 & 0.798 & 0.653 \\
\hline 15 & & & & & & & & & & & & & & & - & 0.735 & 0.703 & 0.784 & 0.796 & 0.701 & 0.710 & 0.597 \\
\hline 16 & & & & & & & & & & & & & & & & - & 0.748 & 0.808 & 0.846 & 0.735 & 0.861 & 0.693 \\
\hline 17 & & & & & & & & & & & & & & & & & - & 0.798 & 0.800 & 0.752 & 0.748 & 0.700 \\
\hline 18 & & & & & & & & & & & & & & & & & & - & 0.810 & 0.756 & 0.825 & 0.653 \\
\hline 19 & & & & & & & & & & & & & & & & & & & - & 0.893 & 0.891 & 0.704 \\
\hline 20 & & & & & & & & & & & & & & & & & & & & - & 0.831 & 0.794 \\
\hline 21 & & & & & & & & & & & & & & & & & & & & & - & 0.687 \\
\hline 22 & & & & & & & & & & & & & & & & & & & & & & - \\
\hline
\end{tabular}

Table 2. Numbers of unique loci shared within each population and number of loci shared by the two populations observed from DNA analysis of Takifugu obscurus

\begin{tabular}{|c|c|c|c|}
\hline \multirow{2}{*}{ Primer } & \multicolumn{2}{|c|}{$\begin{array}{l}\text { No. of unique loci shared within each } \\
\text { population }\end{array}$} & \multirow{2}{*}{$\begin{array}{c}\text { No. of loci shared by the two } \\
\text { populations }\end{array}$} \\
\hline & Natural & Cultured & \\
\hline OPC-03 & 11 & 11 & 0 \\
\hline OPC-05 & 55 & 33 & 44 \\
\hline OPC-06 & 22 & 22 & 0 \\
\hline OPC-07 & 22 & 44 & 0 \\
\hline OPC-11 & 88 & 11 & 0 \\
\hline Total no. & 198 & 121 & 44 \\
\hline Average no. per primer & 39.6 & 24.2 & 8.8 \\
\hline
\end{tabular}

Table 3. Similarity estimates of average bandsharing values (mean $\pm \mathrm{SE}$ ) within/between populations produced in two river pufferfish populations of Takifugu obscurus

\begin{tabular}{ccc}
\hline \hline Population & Natural & Cultured \\
\hline Natural & $0.683 \pm 0.014^{\mathrm{ab}}$ & $0.344 \pm 0.006^{\mathrm{c}}$ \\
Cultured & - & $0.759 \pm 0.009^{\mathrm{a}}$ \\
\hline
\end{tabular}

${ }^{a-c}$ Values with unlike superscript are significantly different, $p<0.05$

Each value is a product of three disparate experiments. 
Israeli carp $(0.57 \pm 0.03)$ (Yoon, 2001), and Geojedo oyster populations $(0.537 \pm 0.017)$ (Kim et al., 2004). In contrast, the average BS value in this study was similar to that of Spanish barbel species (0.71-0.81) (Callejas \& Ochando, 1998). A cuttlefish (Sepia esculenta) population from Sockcho (0.826) exhibited higher BS values than did fish from Seocheon (0.465) (Yoon \& Kim, 2010). Polymorphisms were identified according to the banding patterns of the primer-amplified products at specific sites (Callejas \& Ochando, 1998; Mamuris et al., 1999; Adams, 2000; Bartish et al., 2000; Klinbunga et al., 2000a; Nozaki et al., 2000; Yoon, 2001; Kim et al., 2004; Oh \& Yoon, 2014; Yoon, 2019). Researchers analyzed the size of DNA fragments in the PCR products of black tiger shrimp (Penaeus monodon) (Tassanakajon et al., 1998), blacklip abalone (Haliotis rubra) (Huang et al., 2000), the brittle star (Amphiura filiformis) (McCormack et al., 2000), yellowfin tuna (Thunnus albacares) (Diaz-Jaimes \& Uribe-Alcocer, 2003), lobster species (Park et al., 2005), crayfish (Cambaroides similis) (Kim et al., 2006), cuttlefish (Sepia esculenta) (Yoon \& Kim, 2010), white clam (Meretrix lusoria) (Yoon et al., 2012), and mollusk species (Oh \& Yoon, 2014). The primer revealed significant differences in individuals and populations, resulting from variations in DNA polymorphisms among individuals and populations (Callejas \& Ochando, 1998; Mamuris et al., 1999; Adams, 2000; Bartish et al., 2000; Klinbunga et al., 2000a; Nozaki et al., 2000; Yoon, 2001; Kim et al., 2004; Oh \& Yoon, 2014; Yoon, 2019).

In this study, PCR analysis revealed an important GD between two population/species pairs by discriminating the two river pufferfish based on geographic differences in population, species, and genetic structure. The hierarchical polar dendrogram defined two main clusters, 1 (NATURAL 01NATURAL 11) and 2 (CULTURED 12-CULTURED 22) from two geographic river pufferfish populations, as shown in Fig. 2. The shortest GD exhibiting significant molecular difference was between cultured individuals \# 12 and 15 (GD=0.053). Ultimately, individual \# 02 in the natural river pufferfish population was most distantly related to cultured individual \# 22 (GD=0.827). These results indicate that the cultured river pufferfish population is genetically different from the

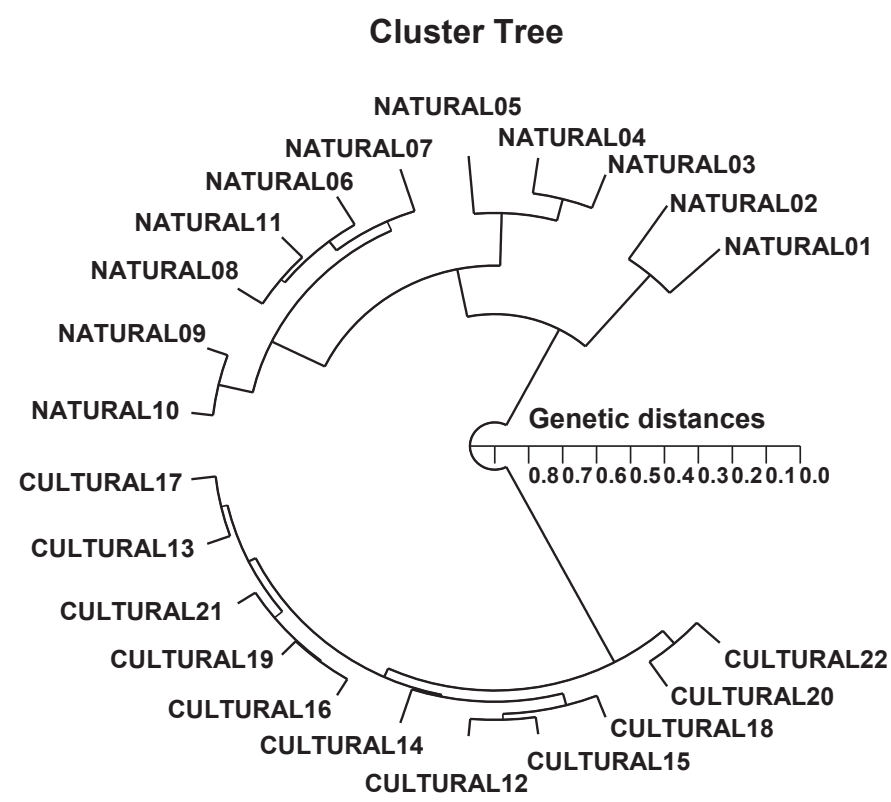

Fig. 2. UPGMA polar dendrogram of genetic distances among natural (NATURAL 01-NATURAL 11) and cultured (CULTURED 12-CULTURED 22), respectively. The structure between unequal individuals within the river pufferfish populations was generated along with the bandsharing values and similarity matrix. UPGMA, unweighted pair group method with arithmetic. 
natural river pufferfish population. A neighbor-joining tree of the GDs between three mud crab species analyzed by PCR indicated the relationships between the species (Klinbunga et al., 2000b). Large genetic differences have been reported between geographically detached populations within and between species. Phylogenetic relationships among 5 Haliotis species and one hybrid species were determined using the distance coefficient and a phylogenetic tree based on PCR data (Kim et al., 2000). Accordingly, two clusters were identified: cluster I comprising H. discus hannai, $H$. discus, H. gigantea, and H. sieboldii, and the hybrid, which was consecutively re-divided into two subclusters. The authors reported that PCR analysis was the predominant method for determining the phylogenetic relationship between 6 Haliotis species. In other invertebrates, a cluster analysis of the pairwise species matrix generated from genetic data revealed possible clustering of geographically close populations of blacklip abalone (Huang et al.,2000).

The foregoing findings indicate the potential of PCR analysis to detect diagnostic markers for the identification of two river pufferfish populations. The findings validate the method as a suitable tool for DNA evaluations, both within and between individuals, populations, and species. The classification of river pufferfish species is based on morphological variations in the tail type, body color, body size, body type, and mouth size. Differences in such traits reflect their separate origin or genetic identity (Chenyambuga et al., 2004). The population relationships indicated by PCR analysis should be consistent with previously acquired data based on morphological analysis (Nebauer et al., 2000).

In general, using several oligonucleotide primers, this PCR technique enables the determination of detailed markers specific to geographic populations, besides genetic diversity and polymorphism in individuals (Partis \& Wells, 1996; Adams, 2000; Bartish et al., 2000; Kim et al., 2000; McCormack et al., 2000; Nozaki et al., 2000; Yoon \& Park, 2002; Kim et al., 2004; Park et al., 2005; Yoon \& Kim, 2010; Hur et al., 2012; Yoon et al., 2012; Song \& Yoon, 2013; Yoon, 2019). Data highlighting the GD of the river pufferfish can be used to determine the increase in individual population as well as the conservation efforts in the inshore and river areas of the Korean peninsula. Nonetheless, additional studies involving larger number of individuals, primers, populations, species, and genera are required to definitively construct the loci for specific taxa and the subsequent interspecific gene flow in the genus Takifugu. Advanced studies including a large number of individual samples and primers are needed to acquire comprehensive data related to the genetic structure of the two river pufferfish populations.

\section{REFERENCES}

Adams RP (2000) Systematics of the one seeded Juniperus of the eastern hemisphere based on leaf essential oils and random amplified polymorphic DNAs (RAPDs). Biochem Syst Ecol 28:529543.

Bartish IV, Garkava LP, Rumpunen K, Nybom H (2000) Phylogenetic relationships and differentiation among and within populations of Chaenomeles Lindl. (Rosaceae) estimated with RAPDs and isozymes. Theor Appl Genet 101:554-563.

Callejas C, Ochando MD (1998) Identification of Spanish barbel species using the RAPD technique.J Fish Biol 53:208-215.

Chang YJ, Lim HK, Chang YJ, Kim HS (1999) Sperm cryopreservation and fertility of post-thaw sperm in river puffer, Takifugu obscurus. J Aqua 12:1-5.

Chenyambuga SW, Hanotte O, Hirbo J, Watts PC, Kemp SJ, Kifaro GC, Gwakisa PS, Petersen PH, Rege JEO (2004) Genetic characterization of indigenous goats of sub-Saharan Africa 
using microsatellite DNA markers. Asian-Australas J Anim Sci 17:445-452.

Diaz-Jaimes P, Uribe-Alcocer M (2003) Allozyme and RAPD variation in the eastern Pacific yellowfin tuna (Thunnus albacares). Fish Bull 101:769-777.

Huang BX, Peakall R, Hanna PJ (2000) Analysis of genetic structure of blacklip abalone (Haliotis rubra) populations using RAPD, minisatellite and microsatellite markers. Mar Biol 136:207216.

Hur YY, Choi YJ, Kim EJ, Yoon MS, Park YS, Jung SM, Noh JH, Park SJ, Ma KH, Park KS (2012) Analysis of genetic relationship of grape rootstock cultivate and wild Vitis species using RAPD and SSR markers. Korean J Breed Sci 44:19-28.

Jeffreys AJ, Morton DB (1987) DNA fingerprints of dogs and cats. Anim Genet 18:1-15.

Kang HW, Chung EY, Kang DY, Jo KC, Park YJ, Jo KC, Kim GH (2008). Gonadal maturation and spawning of river puffer Takifugu obscurus indoor cultured in low salinity. Korean J Fish Aquat Sci 21:331-338.

Kang HW, Shim KB, Kang DY, Jo KC, Song KC, Lee JH, Song HI, Son SG, Cho YJ (2007) Sitological quality evaluation of cultured and wild river puffer, Takifugu obscurus (Abe). Korean J Fish Aquat Sci 20:147-153.

Kim DW, Han KN, Lim YJ (2003) Microstructure of otoliths and early growth of river puffer, Takifugu obscurus. J Korean Soc Ocean 8:237-242.

Kim JY, Park CY, Yoon JM (2004) Genetic differences and DNA polymorphism in oyster (Crassostrea spp.) analysed by RAPD-PCR. Korean J Genet 26:123-134.

Kim S, Kim YH, Yoon JM (2006) Genetic variation in geographic crayfish (Cambaroides similis) populations. J Fish Pathol 19:141-153.

Kim SK, Jung YH, Han SH, Oh YS, Ko MH, Oh MY (2000) Phylogenetic relationship among Haliotis spp. distributed in Korea by the RAPD analysis. Korean J Genet 22:43-49.

Kim YS, Yoon JM (2018) Genetic distances in two Gracilaria species (Gracilariaceae, Rhodophyta) identified by PCR technique. Dev Reprod 22:393-402.

Klinbunga S, Ampayup P, Tassanakajon A, Jarayabhand P, Yoosukh W. (2000a) Development of species-specific markers of the tropical oyster (Crassostrea belcheri) in Thailand. Mar Biotechnol 2:476-484.

Klinbunga S, Boonyapakdee A, Pratoomchat B (2000b) Genetic diversity and species-diagnostic markers of mud crabs (Genus Scylla) in Eastern Thailand determined by RAPD analysis. Mar Biotechnol 2:180-187.

Lee BG, Heo MG, Kim YU, Choe JS, Kim BG (2004a). Effects of water temperature on the growth and haematological response of juvenile river puffer, Takifugu obscurus. Korean J Ichthyol 16:27-33.

Lee JS, Lee KT, Kim DH, Kim JH, Han KN (2004b) Acute toxicity of dissolved inorganic metals, organotins and polycyclic aromatic hydrocarbons to puffer fish, Takifugu obscurus. J Environ Toxicol 19:141-151.

Mamuris Z, Stamatis C, Bani M, Triantaphyllidis C (1999) Taxonomic relationships between four species of the Mullidae family revealed by three genetic methods: allozymes, random amplified polymorpic DNA and mitochondrial DNA.J Fish Biol 55:572-587.

McCormack GP, Powell R, Keegan BF (2000) Comparative analysis of two populations of the brittle star Amphiura filiformis (Echinodermata: Ophiuroidae) with different life history strategies using RAPD markers. Mar Biotechnol 2:100-106.

Muchmore ME, Moy GW, Swanson WJ, Vacquier VD (1998) Direct sequencing of genomic DNA for characterization of a satellite DNA in five species of Eastern Pacific abalone. Mol Mar Biol Biotech 7 :1-6. 
Nebauer SG, del Castillo-Agudo L, Segura J (2000) An assessment of genetic relationships within the genus Digitalis based on PCR-generated RAPD markers. Theor Appl Genet 100:12091216.

Nozaki T, Mishiba K, Mii M, T. Koba T (2000) Construction of synteny groups of Brassica alboglabra by RAPD markers and detection of chromosome aberrations and distorted transmission under the genetic background of B. campestris. Theor Appl Genet 101:538-546.

Oh H, Yoon JM (2014) Genetic distances of three mollusk species investigated by PCR analysis. Dev Reprod 18:43-49.

Park SY, Park JS, Yoon JM (2005) Genetic differences and variation in slipper lobster (Ibacus ciliatus) and deep sea lobster (Puerulus sewelli) determined by RAPD analysis. Korean J Genet 27:307-317.

Partis L, Wells RJ (1996) Identification of fish species using random amplified polymorphic DNA (RAPD). Mol Cell Probes 10:435-441.

Song YJ, Yoon JM (2013) Genetic differences of three Pollicipes mitella populations identified by PCR analysis. Dev Reprod 17:199-205.

Tassanakajon A, Pongsomboon S, Jarayabhand P, Klinbunga S, Boonsaeng V. (1998) Genetic structure in wild populations of black tiger shrimp (Penaeus monodon) using randomly amplified polymorphic DNA analysis. J Mar Biotech 6:249-254.

Yoke-Kqueen C, Radu S (2006) Random amplified polymorphic DNA analysis of genetically modified organisms.J Biotechnol 127:161-166.

Yoo GY, Bai SC (2014) Effects of dietary lipid sources and essential fatty acids on the growth and body composition of the juvenile river puffer fish Takifugu obscurus. Korean J Fish Aquat Sci 47:390-398.

Yoo GY, Yun HH, Bai SC (2014) Optimum dietary protein level in juvenile river puffer Takifugu obscurus. J Fish Mar Sci Educ 26:915-922.

Yoon JM (2001) Genetic similarity and difference between common carp and Israeli carp (Cyprinus carpio) based on random amplified polymorphic DNAs analyses. Korean J Biol Sci 5:333-339.

Yoon JM (2019) Genetic distances between two cultured Penaeid shrimp (Penaeus chinensis) populations determined by PCR analysis. Dev Reprod 23:193-198.

Yoon JM, Kim JY (2010) Genetic differences and geographic variation in cuttle fish (Sepia esculenta Hoyle). Dev Reprod 14:163-170.

Yoon JM, Park HY (2002) Genetic similarity and variation in the cultured and wild crucian carp (Carassius carassius) estimated with random amplified polymorphic DNA. Asian-Australas J Anim Sci 15:470-476.

Yoon JM, Park KI, Choi SH (2012) Variation of shell color in three geographic white clam (Meretrix lusoria) populations of the Yellow Sea. Dev Reprod 16:47-51.

Zhou L, Wang Y, Gui JF (2000) Analysis of genetic heterogeneity among five gynogenetic clones of silver crucian carp, Carassius auratus gibelio Bloch, based on detection of RAPD molecular markers. Cytogenet Cell Genet 88:133-139. 
